\title{
Perception of Riau Muslim Entrepreneurs on the Merger of Islamic Commercial Banking into Indonesian Islamic Bank
}

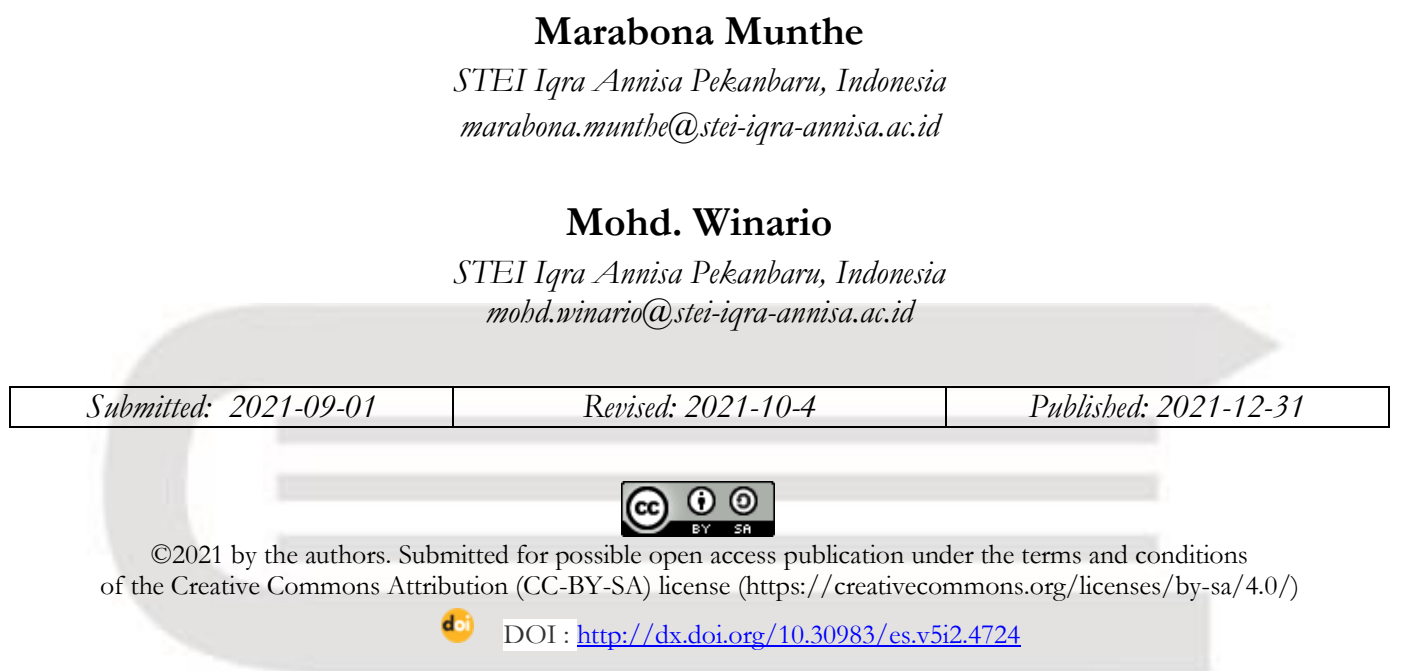

Abstract

The purpose of this study is to further examine the perceptions of Muslim entrepreneurs in Rian towards the merger of a Islamic Commercial Banking to become an Indonesian Islamic bank. The method used is a qualitative method generated from a questionnaire filled out by Muslim entrepreneurs in Riau Province, explaining the perception of Riau Muslims about the merger of Islamic banks under BUMN. The results of this study indicate that the perceptions of Muslim entrepreneurs in Riau towards the joining of Islamic banks as BUMN, in this case Bank. Syariah Mandiri, BNI Syariah and BRI syariah to become Bank. Syariah Indonesia which is abbreviated as BSI in general have different perceptions, there are still many who disagree. by joining the Islamic Bank. under the BUMN. Entrepreneurs are also not too sure about the joining of the Islamic Bank to become the icon and direction of the World Islamic Bank, they think that the joining of the Bank is influenced by political elements among the political elite. However, Muslim entrepreneurs in Riau on average will still become customers of Indonesian Islamic Bank, because apart from being a Islamic bank, there is no better choice than other banks.

Keywords: Perception, Muslim Entrepreneurs, Mergers, Islamic Banks.

\section{Abstrak}

Tujuan penelitian ini adalah untuk mengkaji lebih jauh persepsi pengusaha muslim Riau terhadap penggabungan Bank Syariah BUMN menjadi bank syariah Indonesia. Metode yang digunakan adalah kualitatif yang dihasilkan dari kuisioner yang diisi oleh para pengusaha muslim yang ada di Provinsi Riau, menjelaskan mengenai persepsi muslim riau terhadap mergernya bank syariah di bawah BUMN. Hasil penelitian ini menunjukan bahwa persepsi pengusaha muslim riau terhadap bergabungnya bank syariah di bawah BUMN dalam hal ini Bank Syariah Mandiri, BNI Syariah dan BRI syariah menjadi Bank Syariah Indonesia yang disingkat menjadi BSI secara umum memiliki persepsi yang berbeda-beda, masih banyak yang tidak setuju dengan begabungnya Bank Syariah BUMN tersebut. Pengusaha juga tidak terlalu yakin dengan bergabungnya Bank Syariah tersebut menjadi icon dan kiblat Bank Syariah dunia, mereka menganggap bergabungnya Bank banyak dipengaruhi oleh unsur politis dikalangan elit politik. Namun pengusaha muslim Riau rata-rata tetap akan menjadi Nasabah Bank Syariah Indonesia, karena selain merupakan bank syariah, dan tidak ada pilihan lain yang lebih baik dari bank lain.

Kata Kunci: Persepsi, Pengusaha Muslim, Merger, Bank Syariah. 
EKONOMIKA SYARIAH:

Journal of Economic Studies
e-ISSN: 2614-8110

p-ISSN: 2614-7890

Vol. 5, No. 2, July-Dec 2021

\section{Introduction}

The growth of Islamic banking over the last three years has increased significantly compared to 2015 , from $8.78 \%$ to above $12.00 \%$. The year 2015 can be said to be the lowest point of Islamic banking growth over the last ten years, where the growth of conventional banking is almost the same as Islamic banking, namely $8.55 \%$ and $8.78 \%$.

Data from the Financial Services Authority (OJK) shows that Islamic banking assets continue to increase with growth approaching $20.00 \%$. This is an early sign that Islamic banking is starting to recover. However, it should be noted that this growth was the result of the conversion of Bank Aceh and Bank Nusa Tenggara Barat (NTB), not the result of the organic growth of existing Islamic Commercial Banks (BUS). Thus, the plans of several regional banks that are conducting studies for conversion should be encouraged so that it is hoped that the momentum for Islamic banking growth will remain high. Triggered by the conversion and spin-off of 22 Sharia Business Units before 2023, it is hoped that the industry's growth momentum will be able to approach the full ideal level, which is in the range of $20-30 \%$.

(KNKS, 2019).

Table 1 Performence of BNI Syariah Bank

\begin{tabular}{lcr}
\hline \multicolumn{1}{c}{ Bank Name } & \multicolumn{2}{c}{$\begin{array}{c}\text { BRI } \\
\text { Syariah }\end{array}$} \\
\hline \multicolumn{1}{c}{ Years } & 2019 & 2020 \\
\hline Total Assets & 43,12 & 57,70 \\
\hline Financing & 34,12 & 49,34 \\
\hline Third-party funds & 27,38 & 40,0 \\
\hline Profit & 0,074 & 0,25 \\
\hline
\end{tabular}

Table 2 Performence of BRI Syariah Bank

\begin{tabular}{lrr}
\hline \multicolumn{1}{c}{ Bank Name } & \multicolumn{2}{c}{ BNI } \\
\multicolumn{1}{c}{ Yyariah Bank } \\
\hline Years & $\mathbf{2 0 1 9}$ & $\mathbf{2 0 2 0}$ \\
\hline Total Assets & 44,98 & 55,01 \\
\hline Financing & 43,77 & 47,97 \\
\hline Third-party funds & 32,58 & 33,05 \\
\hline Profit & 0,6 & 0,5 \\
\hline
\end{tabular}

Table 3 Performance of Mandiri Syariah Bank

\begin{tabular}{lcr}
\hline \multicolumn{1}{c}{ Bank name } & \multicolumn{2}{c}{ Mandiri Syariah Bank } \\
\hline \multicolumn{1}{c}{ Years } & $\mathbf{2 0 1 9}$ & $\mathbf{2 0 2 0}$ \\
\hline Total Assets & 112,29 & 126,85 \\
\hline Financing & 99,81 & 112,58 \\
\hline Third-party funds & 75,54 & 83,43 \\
\hline Profit & 1,28 & 1,43 \\
\hline
\end{tabular}

Table 4 Performance After Conversion to Indonesian Islamic Bank

\begin{tabular}{|c|c|}
\hline Bank name & $\begin{array}{c}\text { Indonesian Islamic } \\
\text { Bank }\end{array}$ \\
\hline Years & Per- Des' 2020 \\
\hline Total Assets & 239,56 \\
\hline Financing & 209,98 \\
\hline Third-party funds & 156,51 \\
\hline Profit & 2,19 \\
\hline
\end{tabular}

Based on the data in the tables above, it can be seen that each Islamic Bank, as a subsidiary of a State-Owned Enterprise Bank (BUMN) tends to be positive in terms of its annual increase in terms of growth in total assets, disbursed financing and increased profits including when it was merged as seen in the data as of December 2020 where the total assets of Indonesian Islamic Bank were 239.56 trillion, meanwhile the financing disbursed was Rp. 209.98 trillion, and third party funds of Rp. 156.51 trillion and profits reached 2.19 trillion. These data show 
positive things for the development and growth of Indonesian Islamic Banks in the future.

Indonesian Islamic Bank (BSI) as a result of the merger of 3 (three) stateowned Islamic banks, became the 7 th largest bank in Indonesia based on the value of assets owned. At the beginning of its operation, it has been able to become a magnet for many business actors and investors in the stock market as indicated by a significant increase in share value. Business actors also gave a positive assessment and had high hopes for BSI's progress as a financial institution that could become a driving force for the national economy. Even though many economists hope that the government's support for the change in the status of each bank will not only accelerate the merger but also increase capital so that the range of projects that can be financed by Indonesian Islamic Bank will eventually reach large and large-scale projects.

This initial success must be followed by success in responding to the challenges of achieving a world-class vision and being able to become a driver of the national economy, among others through continuous business transformation efforts, producing competitive financial service products and increasing penetration of financing facilitation for Micro Small Medium Enterprises (MSMEs). For this reason, the Dewan Perwakilan Rakyat (DPR) through its supervisory function needs to continue to oversee and encourage the development of this Indonesian Islamic Bank so that it plays a role in improving the economy and is able to achieve the aspired vision in 2025.

The purpose of the merger of Islamic banks is basically to encourage Islamic banks to become bigger so that they can enter the global market and become a catalyst for Islamic economic growth in Indonesia. In addition, the merger of Islamic banks is considered to be more efficient in fundraising, operations and corporate spending. ${ }^{1}$ Through the merger of Islamic banks, it is hoped that Islamic banking will continue to grow and become a new energy for the national economy and will become a bank that is parallel to other State-Owned Enterprises (BUMN) banks so that it is beneficial in terms of policy and bank transformation (Republika, 13 October 2020).

As of December 2020, BSI's assets have reached Rp239.56 trillion (see Table 1). This amount of assets puts BSI as the 7th largest bank in Indonesia in terms of assets. The bank's assets, codenamed BRIS, are below PT Bank CIMB Niaga Tbk (Rp281.7 trillion) and above PT Bank Panin Tbk (Rp216.59 trillion) as of September 2020 (Bisnis Indonesia, February 2, 2021). This huge asset can spur greater ability to support financing. ${ }^{2}$

The merging of the three banks under the BUMN triggers both positive and negative sides. In this study the authors hope for more positive sides. Then from a

1 Fauziah Nur Hutauruk, 'Ukuran Perusahaan Sebagai Pemoderasi Dalam Hubungan Profitabilitas Dan Likuiditas Terhadap Struktur Modal Bank Umum Syariah', EKONOMIKA SYARIAH: Journal of Economic Studies, 4.2 (2020), 136 <https://doi.org/10.30983/es.v4i2.3633>.

${ }^{2}$ Achmad Sani Alhusain, Bank Syariah

Indonesia: Tantangan Dan Strategi Dalam Mendorong Perekonomian Nasional, Pusat Penelitian Keahlian DPR RI, Bidang Ekonomi Dan Kebijakan Publik Info Singkat Kajian Singkat Terhadap Isu Aktual Dan Strategis Badan, Vol. XIII, No.3/I/Puslit/Februari/2021. 
political perspective there are things that need to be straightened out, for example, why should Islamic Bank of BUMN be merged, why not one of the existing and large BUMN banks which is directly converted to sharia so that it is easier, more efficient and the possibility is also greater . This is related to the different perceptions of entrepreneurs in Riau province.

According to Marabona Munthe, Islamic banks are required to have products that are pro to micro, small and medium entrepreneurs so that it can be said that Islamic banks are involved in assisting the implementation of poverty alleviation which is part of the sustainable development goals program. Furthermore, the nature of the existence of Islamic financial institutions can help create social welfare or social well-being, while in terms of financial transactions if more and more people use Islamic banks, it can be one of the mitigations of the economic crisis ${ }^{3}$. Indonesia's economic conditions are supported by micro, small and medium enterprises (MSMEs). This is indicated by the presence of micro, small and medium entrepreneurs who make up $99.9 \%$ of business actors in Indonesia ${ }^{4}$.

According to Aribawa (2016), MSMEs are a business segment that can withstand the storm of the economic crisis caused by the decline in the rupiah against the US dollar, which is due to the low import component in their business raw

3 Marabona Munthe, Fatwa Bunga Bank Perspektif Maqashid Syariah, Jurnal Ekonomi Islam Al-Amwal Vol 9, No. 1, Juni 2020.

4 Suci, Y.R., 2017. Perkembangan UMKM (Usaha mikro kecil dan menengah) di Indonesia. Cano Ekonomos, 6(1), pp.51-58. materials ${ }^{5}$. In addition, the MSME sector can also be the frontline for the government in alleviating poverty because the MSME sector is the largest sector that absorbs a lot of labor (labor intensive) so that it can reduce unemployment ${ }^{6}$.

Riau Muslim entrepreneurs in this regard also have their own views with the joining of three state-owned Islamic banks, some agree and some do not, with their own reasons. Therefore, it is necessary to study further to discuss the perceptions of these Muslim entrepreneurs.

Based on this background, the author will study further regarding the merger of Islamic banks with the theme of the perception of Riau Muslim entrepreneurs on the merger of Islamic banks under BUMN into Indonesian Islamic banks.

\section{Theoretical Basis \\ Perception}

According to the Big Indonesian Dictionary, perception is a direct response (acceptance) of something or is the process of someone knowing things through the five senses. Perception, according to Rakhmat Jalaludin (1998) is the experience of objects, events, or relationships obtained by inferring information and interpreting messages.

In general, perception can be interpreted as a cognitive process experienced by everyone in understanding any information about the environment

${ }^{5}$ Aribawa, D., 2016. Pengaruh literasi keuangan terhadap kinerja dan keberlangsungan UMKM di Jawa Tengah. Jurnal Siasat Bisnis, 20(1), 1-13.

${ }^{6}$ Purnamasari, F., \& Darmawan, A., 2017. Islamic Banking and Empowerment of Small Medium Enterprise. Etikonomi, 16(2), 221-230. 
through their five senses (sight, hearing, smell, touch, taste). This happens because perception involves individual interpretation of a particular object, so each individual will have a different perception even though they see the same object.

Another definition of perception is a complex process that causes a person to receive or summarize information obtained from his environment. Perception can be formulated as a process of receiving, selecting, organizing, and giving meaning to the stimuli received.

\section{Bank, Banking and Islamic Bank}

According to Law no. 21 of 2008 concerning Islamic banking, Islamic banks are banks that carry out their business activities based on sharia principles and by type consist of Islamic Commercial Banks, Islamic Business Units, and Islamic Rural Banks. $^{7}$

According to the Law of the Republic of Indonesia No. 21 of 2008 concerning Banking Article 1 Paragraph 2 Bank is a business entity that collects funds from the public in the form of deposits and distributes them to the public in the form of credit and/or other forms in order to improve the people's standard of living. Meanwhile, Islamic Commercial Banks are Islamic Banks which in their activities provide services in payment traffic. Meanwhile, according to the Law of the Republic of Indonesia No. 21 of 2008 concerning Banking Article 1 Paragraph 9 Islamic Rural Bank (BPRS) is a Islamic Bank which in its activities does not provide services in payment traffic.

\footnotetext{
${ }^{7}$ Marabona Munthe. 2020, Lembaga Keuangan Syariah (Bank dan Non Bank), Jakarta: Pustaka Amanah, h. 23.
}

Islam is a comprehensive religion and is used as a guide and way of life for its people (way of life), so that Islam not only regulates the spiritual life but also the social life of its people, which is called Hablum minallab and Hablum minannas. Furthermore, in Islamic law there are two types of law, the first is the figh of Ibadah (worship) and the second is the fiqh of muamalah. Unlike the Fiqh of Worship which regulates the worship of prayer, fasting, zakat and hajj, while the figh of muamalah has a broad scope and is characterized by flexibility and flexibility. The essence of the difference between the fiqh of worship and the fiqh of muamalah is that the fiqh of worship whose legal origin is prohibited while the legal origin of muamalah fiqh is permitted. Therefore, all kinds of worship that do not have an order are forbidden, while in muamalah, as long as the activity is allowed or permissible.

Islamic banks have their own advantages compared to conventional banks. When customers are unable to pay, Islamic banks provide convenience by restructuring and rescheduling. This process is relatively easy and has many options for customers, for example the Hasanah Islamic Rural Bank (BPRS), which provides rescheduling for customers who are unable to pay the amount that has been previously agreed upon with various considerations, without adding additional financing. and without increasing the margin. The Bank also provides restructuring and reconditioning to customers in accordance

\footnotetext{
${ }^{8}$ Nurcholis, M., 2018. Ihdad bagi suami dalam kompilasi bukum islam perspektif maqasid al-shariah. Falasifa: jurnal studi keislaman, 8(2), 214-228.
} 
with the agreement. ${ }^{9}$ Apart from the Hasanah Islamic Rural Bank, BRI Syariah also provides rescheduling for customers who are unable to pay, without increasing the margin. The Bank also provides restructuring and reconditioning to customers according to the agreement. ${ }^{10}$ The same thing as done by regional banks, namely Bank Aceh, Bank Syariah NTB and Bank Riau Kepri Syariah providing rescheduling for customers who are unable to pay, without increasing margin. The Bank also provides restructuring and reconditioning to customers in accordance with the agreement. ${ }^{11}$.

Islamic bank agreements are also known in the community, even among students. This is in line with the program to introduce Islamic economics and Islamic bank agreements in Teluk Kuantan, Kuantan Singingi Regency which was well organized and ran smoothly according to the activity plan that had been prepared, although not all of the counseling participants had mastered the material presented well. This activity received a very good reception as evidenced by the active participation of participants in the

${ }^{9}$ Mohd. Winario dan Husni Fuaddi, Penerapan Fatwa DSN MUI pada Pembiayaan Murabahah BPRS Hasanab Pekanbaru, Islamic Business and Finance (IBF), Vol. 1, No. 2, Oktober 2020.

${ }^{10}$ Khairatun Hisan, Riski Syahpitri, and Zulkarnaini Zulkarnaini, 'Determinants of Financing Disbursed by Islamic Rural Banks (BPRS) in Indonesia', EKONOMIKA SYARLAH: Journal of Economic Studies, 5.1 (2021), 50-58.

11 Mohd. Winario, dkk, Analisis Penerapan Pembiayaan Akad Murabahah Bank Rakyat Indonesia Syariah (Bri Syariab) Pekanbaru, Indonesian Interdisciplinary Journal of Sharia Economics (IIJSE) vol. 3. No. 1 Juli 2020. introduction of Islamic economics and Islamic banking agreements by not leaving the place before the activity time ended. ${ }^{12}$.

The public already knows which bank should be chosen to support their financial transactions, because there is already a fatwa stating that bank interest has been forbidden by Majelis Ulama Indonesia (MUI). Based on the kulliyatu al-sitt aspect, the prohibition of bank interest through the fatwa of the MUI number 01 of 2004 has resulted in the benefit of the ummah in general, both concerning matters relating to the maintenance of religion, life, property, mind, lineage/honor and justice. The harm of bank interest is stronger than its benefits, so the researcher argues that it is forbidden and the conclusion of this researcher is at the same time a reinforcement for the fatwa that has been decided by the MUI ${ }^{13}$

The development of Micro, Small and Medium Enterprises (MSMEs) as one of the pillars of the national economy in Indonesia is certainly inseparable from various kinds of problems, such as limited capital, both working and investment, good quality raw materials are difficult to obtain, limited technology, quality resources. good human resources, market information, and difficulty in marketing. The development of this MSME business must increase its production capacity which of course requires a large amount of capital. The lack of capital and the low ability and knowledge of human resources (HR) in managing

${ }^{12}$ Mohd. Winario dan M. Khoir AlKusyairi, pengenalan ekonomi islam dan akadakad bank syariah di smk kab. Kuantan singingi, Jurnal Pengabdian Masyarakat Multidisiplin, Volume 2 No. 1 | Oktober 2018 : Hal :3643.

13 Marabona Munthe, 2020. Fatwa Bunga Bank Perspektif Maqashid Syariah. Jakarta: Pustaka Amanah, h. 84 
businesses, have made MSMEs unable to keep pace with changing consumer tastes and not yet globally competitive (LPPI and BI, 2015). This sometimes makes the majority of MSMEs operate in a relatively short time, which is less than 10 years. ${ }^{14}$ This fact is one of the reasons for the need for the merged Indonesian Islamic Bank to be able to contribute in providing capital for the MSMEs.

\section{Research Method}

This research uses the method of determining the sample, namely the random sampling method where the sample used is random. The data used in this study are primary data and secondary data. To support the research, actual data is needed. The method used is a qualitative method resulting from a questionnaire filled out by Muslim entrepreneurs in Riau Province, explaining the perception of Riau Muslim entrepreneurs on the merger of BUMN Islamic banks into Indonesian Islamic Banks.

\section{Discussion}

\section{Characteristics of Respondent Age}

Based on the results of the questionnaire that has been distributed to respondents, in this case Muslim entrepreneurs in Riau province, the following data can be presented on respondents based on the age of owners of micro, small and medium enterprises (MSMEs) and large-scale entrepreneurs, namely:

14 Diana, Rita. 2019. "Analisis Aksesibilitas Permodalan Mikro Kecil Pada Lemabag Formal Di Provinsi Sumatera Barat." Jurnal Ekonomi Dan Pembangunan 27(01).

Marabona Munthe \& Mohd. Winario.
Table 5 Respondents Age Data

\begin{tabular}{cccc}
\hline No & $\begin{array}{c}\text { Age } \\
\text { (Year) }\end{array}$ & $\begin{array}{c}\text { Respondent } \\
\text { (Person) }\end{array}$ & $\begin{array}{c}\text { Percentage } \\
\mathbf{( \% )}\end{array}$ \\
\hline $\mathbf{1}$ & $<25$ & 9 & 12,86 \\
\hline $\mathbf{2}$ & $25-30$ & 14 & 20,00 \\
\hline $\mathbf{3}$ & $30-35$ & 16 & 22,86 \\
\hline $\mathbf{4}$ & $35-40$ & 16 & 22,86 \\
\hline $\mathbf{5}$ & $>40$ & 15 & 21,43 \\
\hline \multicolumn{2}{c}{ Amount } & 70 & 100 \\
\hline
\end{tabular}

Data Source: Processed Data

Based on table 5 , it can be seen sequentially that the number of respondents under the age of 25 years is 9 respondents $(12.86 \%)$, aged 25 to 30 years is 14 respondents (20\%, aged 30 years to 35 years is 16 years). respondents $(22.86 \%), 16$ respondents $(22.86 \%), 35$ years to 40 years, and 15 respondents over 4 years $(21.43 \%)$. Based on this, it can be said that the age of Muslim entrepreneurs in Riau is very varied because the number almost the same in terms of age.

\section{Characteristics of Respondents}

Education

The results obtained from the questionnaire that has been filled out by Riau Muslim entrepreneurs, based on education are listed in table 6 below:

Table 6 Characteristics of Education

\begin{tabular}{cccc}
\hline No & $\begin{array}{c}\text { Age } \\
\text { (Year) }\end{array}$ & $\begin{array}{c}\text { Respondent } \\
\text { (Person) }\end{array}$ & $\begin{array}{c}\text { Percentage } \\
\text { (\%) }\end{array}$ \\
\hline 1 & Senior & 11 & \\
& High & & 15,71 \\
\hline & School & & 84,29 \\
\hline 2 & Bachelor & 59 & 100
\end{tabular}

Data Source: Processed Data

Based on the table above, it can be seen that the number of respondents based on education level is as follows: SMA or the equivalent is 11 respondents $(15.71 \%)$ and Bachelor or the equivalent is 59 respondents $(84.29 \%)$. Thus, from the 
results of the questionnaire, the education of the majority of Riau's Muslim entrepreneurs has a bachelor's degree, which is $84.29 \%$.

\section{Characteristics of Respondents' Type of Business}

The type of respondent's business based on the results of the questionnaires that have filled out the questionnaires from the researchers who have been distributed can be seen in table 4 below:

Table 7 Characteristics of Business Type

\begin{tabular}{cccc}
\hline No & $\begin{array}{c}\text { Business } \\
\text { Type }\end{array}$ & $\begin{array}{c}\text { Respondent } \\
\text { (Person) }\end{array}$ & $\begin{array}{c}\text { Percentage } \\
\mathbf{( \% )}\end{array}$ \\
\hline 1 & Service & 13 & 18,57 \\
\hline 2 & Food & 18 & 25,71 \\
\hline 3 & Medicines & 6 & 8,57 \\
\hline 4 & Online shop & 8 & 11,43 \\
\hline 5 & Clothes & 5 & 7,14 \\
\hline 6 & Household & 8 & 11,43 \\
& appliances & & 2,86 \\
\hline 7 & Farm & 2 & 11,43 \\
\hline 8 & Basic food & 8 & 2,86 \\
\hline 9 & Travel & 2 & $\mathbf{1 0 0}$ \\
\hline & Amount & $\mathbf{7 0}$ &
\end{tabular}

Data Source: Processed Data

Based on table 7 above, it can be seen that the number of respondents based on the type of business is as follows: service sector as many as 13 respondents $(18.57 \%)$, food/beverage as many as 18 respondents (25.71\%), medicine as many as 6 respondents ( $8.57 \%)$, online shop as many as 8 respondents $(11.43 \%)$, clothing as many as 5 respondents $(7.14 \%)$, household appliances as many as 8 respondents (11.43\%), fisheries/livestock 2 respondents (2, 86\%), basic necessities as many as 8 respondents $(11.43 \%)$, and travel as many as 2 respondents $(2.86 \%)$.

\section{Karakteristik Domisili Usaha} Responden

The characteristics of the respondent's business domicile based on the results of the questionnaires that have been filled out by the researchers who have been distributed are shown in table 4 below:

Table 8 Business Domicile

\begin{tabular}{cccc}
\hline No & District/City & $\begin{array}{c}\text { Respondent } \\
\text { (Person) }\end{array}$ & $\begin{array}{c}\text { Percentage } \\
\mathbf{( \% )}\end{array}$ \\
\hline 1 & Bengkalis & 2 & 2,86 \\
\hline 2 & Indragiri Hilir & 1 & 1,43 \\
\hline 3 & Kampar & 11 & 15,71 \\
\hline 4 & Kepulauan & 2 & 2,86 \\
\hline & Meranti & 2 & 68,57 \\
\hline 5 & Pekanbaru & 48 & 4,29 \\
\hline 6 & Rokan Hilir & 3 & 1,43 \\
\hline 7 & Rokan Hulu & 1 & 2,86 \\
\hline 8 & Siak & 2 & $\mathbf{1 0 0}$ \\
\hline & Amount & $\mathbf{7 0}$ & \\
\hline
\end{tabular}

Data Source: Processed Data

Based on table 8 above, it can be seen that the respondents who have filled out the research questionnaire come from 8 regencies/cities that can represent 12 regencies/cities in Riau Province. The highest number was in the provincial capital, Pekanbaru, reaching 48 respondents (68.57\%), followed by Kampar district with 11 respondents $(15,71 \%)$ and the least in Indragiri Hilir and Rokan Hulu districts with 1 respondent each $(1.43 \%)$.

Perceptions of Riau Muslim Entrepreneurs Against the Merger of Islamic Banks Under BUMN

The perception of Riau Muslim entrepreneurs on the merger of state-owned Islamic banks, such as Bank Syariah Mandiri, BNI Syariah, and BRI Syariah into Indonesian Islamic Bank, has many perceptions among the public, entrepreneurs and many parties. Even the 
existence of impartiality of Islamic banks to small and medium entrepreneurs, because Islamic banks are the largest and exclusive to the upper middle class. The following is the customer's perception in this case is the Riau Muslim Entrepreneur.

Entrepreneurs Have Accounts at Bank Syariah Mandiri (BSM), BNI Syariah (BNIS), BRI Syariah (BRIS)

Based on the results of the questionnaire that the author has distributed to the respondents of Riau Muslim Entrepreneurs, the data obtained from entrepreneurs who have accounts and those who do not have accounts at the three banks are as follows:

Table 9 BSM, BRIS and BNIS Account Ownership

\begin{tabular}{llcc}
\hline No & Bank account & Amount & Percentage \\
\hline 1 & Own & 63 & 90 \\
\hline 2 & Do not have & 7 & 10 \\
\hline & Amount & $\mathbf{7 0}$ & $\mathbf{1 0 0}$
\end{tabular}

Data Source: Processed Data

Based on the table above, it can be seen that not all respondents have an account at one of the 3 merged BUMN Islamic Banks. A total of 63 respondents or $(90 \%)$ have an account at one of these banks, while 7 respondents $(10 \%)$ do not. These data indicate that the majority of respondents are customers of one of these Islamic banks.

Length of Ownership of Islamic Bank Accounts Under BUMN

Based on the results of the questionnaire that the author distributed through questionnaires, it was found that Riau Muslim entrepreneurs who had accounts at the merged BUMN Syariah Banks were 63 respondents $(90 \%)$, the details are as follows:
Table 10 Length of Ownership of BSM, BRIS and BNIS Accounts

\begin{tabular}{cccc}
\hline No & $\begin{array}{c}\text { Time of } \\
\text { Account } \\
\text { (years) }\end{array}$ & $\begin{array}{c}\text { Respondent } \\
\text { (Person) }\end{array}$ & $\begin{array}{c}\text { Percentage } \\
\mathbf{( \% )}\end{array}$ \\
\hline $\mathbf{1}$ & $>\mathbf{1}$ & $\mathbf{6}$ & 9.52 \\
\hline $\mathbf{2}$ & $\mathbf{1 - 3}$ & $\mathbf{1 6}$ & 25.40 \\
\hline $\mathbf{3}$ & $\mathbf{3 - 5}$ & $\mathbf{1 4}$ & 22.22 \\
\hline $\mathbf{4}$ & $\mathbf{5 - 7}$ & $\mathbf{6}$ & 9.52 \\
\hline $\mathbf{5}$ & $\mathbf{7 - 1 0}$ & $\mathbf{6}$ & 9.52 \\
\hline $\mathbf{6}$ & $\mathbf{> 1 0}$ & $\mathbf{1 5}$ & 23.81 \\
\hline & Amount & $\mathbf{6 3}$ & $\mathbf{1 0 0}$ \\
\hline
\end{tabular}

Data Source: Processed Data

Based on the table data above, it can be explained that on average, Riau Muslim entrepreneurs have been customers for a long time, of which only 6 respondents $(9.52 \%)$ have just had a merged BUMN sharia bank account, while the rest are 1 year to 3 years old. respondents $(25.40 \%), 3$ years to 5 years 14 respondents $(22.22 \%), 5$ years to 7 years 6 respondents $(9.52 \%), 7$ years to 10 years 6 respondents $(9.52 \%)$ and above 10 years as many as 15 respondents $(23.81 \%)$.

\section{Respondents Who Have Done} Financing At Islamic Banks

Based on the questionnaires that have been distributed, not all of the Riau Muslim Entrepreneurs who responded to the questionnaires that have been distributed have ever done financing at the BUMN Islamic bank. This can be seen in the table below:

Table 11 Entrepreneurs Doing Financing at State-Owned Sharia Banks

\begin{tabular}{clcc}
\hline No & Category & Amount & Percentage \\
\hline 1 & Once & 34 & 48,57 \\
\hline 2 & Never & 36 & 51,43 \\
\hline & Amount & 70 & 100
\end{tabular}

Data Source: Processed Data 
From the table above, it can be explained that there are 34 respondents $(48.57 \%)$ of entrepreneurs/customers who have done financing, while 36 percent of those who have never done financing. This can be interpreted that there are still many Riau Muslim entrepreneurs who have not done financing through Islamic banks under BUMN.

\section{Reasons for Financing at Islamic Banks}

Based on the questionnaire that was distributed, it was found that Muslim entrepreneurs in Riau have varied reasons for financing Islamic banks under BUMN. This can be seen in the table below:

Banks

\begin{tabular}{llll}
\hline No & Category & Amount & Percentage \\
\hline 1 & $\begin{array}{l}\text { Share the } \\
\text { Results Clear }\end{array}$ & 6 & 8,57 \\
\hline 2 & $\begin{array}{l}\text { Many } \\
\text { Recommend }\end{array}$ & 5 & 7,14 \\
\hline 3 & $\begin{array}{l}\text { Because it's } \\
\text { Halal and } \\
\text { Blessing }\end{array}$ & 36 & \\
& Easy Process & 3 & 51,43 \\
\hline 4 & Do not know & 20 & 28,57 \\
\hline 5 & Amount & $\mathbf{7 0}$ & $\mathbf{1 0 0}$ \\
\hline
\end{tabular}

Sumber Data: Data Olahan

From the table above, it can be explained that there are 36 respondents $(51.43 \%)$ who do financing at Islamic banks who are justified because they are halal and blessed, the rest are reasoned that there is a clear profit sharing, many recommend, and the process is easy, and the amount is Rp. $20 \%$ answered don't know. Regarding the reasons for choosing a sharia bank, Muslims are also influenced by the MUI fatwa number 01 of 2004 concerning bank interest which clearly states that bank interest meets the criteria for usury transactions so it was decided that the law on bank interest is haram (Marabona Munthe: 2020).

The next step is to find out the perception response of Riau Muslim entrepreneurs to the merger of Islamic Banks under BUMN to become Indonesian Islamic Banks (BSI), which can be seen in the table below:

Table 13 Recapitulation of Riau Muslim Entrepreneurs' Perceptions of the Merger of State-Owned Sharia Banks

\begin{tabular}{|c|c|c|c|c|}
\hline No & Category & Yes & No & $\begin{array}{c}\text { Doubtf } \\
\text { ul }\end{array}$ \\
\hline \multirow[t]{3}{*}{1} & Knowing Bank & & \multirow{3}{*}{22,86} & \multirow{3}{*}{0} \\
\hline & Merger Syariah & 77,14 & & \\
\hline & BUMN. & & & \\
\hline \multirow[t]{3}{*}{2} & Remain a & & \multirow{3}{*}{2,86} & \multirow{3}{*}{22,86} \\
\hline & $\begin{array}{l}\text { customer after } \\
\text { the merger of }\end{array}$ & \multirow[t]{2}{*}{74,29} & & \\
\hline & Islamic Banks. & & & \\
\hline \multirow[t]{8}{*}{3} & BSI Will & \multirow{8}{*}{22,86} & \multirow{8}{*}{28,57} & \multirow{8}{*}{48,57} \\
\hline & Become An & & & \\
\hline & Exclusive Bank & & & \\
\hline & In The Means & & & \\
\hline & Of Financing & & & \\
\hline & Only For The & & & \\
\hline & Middle And & & & \\
\hline & Up. & & & \\
\hline \multirow[t]{13}{*}{4} & The & & \multirow{13}{*}{52,86} & \multirow{13}{*}{0} \\
\hline & Knowledge & & & \\
\hline & Table of Bank & & & \\
\hline & Indonesia & & & \\
\hline & Regulation & & & \\
\hline & (PBI) Number & & & \\
\hline & 17 of 2015 & 47,14 & & \\
\hline & concerning & & & \\
\hline & MSMEs states & & & \\
\hline & that the & & & \\
\hline & banking world & & & \\
\hline & must allocate & & & \\
\hline & credit. & & & \\
\hline \multirow[t]{3}{*}{5} & BSI Prioritizes & & & \\
\hline & MSMEs by & 35,71 & 18,57 & 45,71 \\
\hline & $20 \%$ & & & \\
\hline \multirow[t]{4}{*}{6} & This BSI Can & \multirow{4}{*}{42,86} & \multirow{4}{*}{15,71} & \multirow{4}{*}{41,43} \\
\hline & Be Effective & & & \\
\hline & November & & & \\
\hline & 2021. & & & \\
\hline 7 & $\begin{array}{l}\text { BSI will be } \\
\text { more solid to }\end{array}$ & 48,57 & 10,00 & 41,43 \\
\hline
\end{tabular}




\begin{tabular}{ll}
\hline \multicolumn{3}{c}{ be the best or } \\
even vice versa \\
\hline $8 \quad$ The Merger of \\
Bank Syariah \\
Mandiri, BNI \\
Syariah and \\
BRI Syariah, is $31,43 \quad 25,71 \quad 42,86$ \\
Influenced by \\
Political \\
Elements. \\
Bank Syariah \\
Mandiri, BNI \\
Syariah and \\
BRI Syariah \\
because of the \\
many problems \\
that arise so \\
that these \\
banks.
\end{tabular}

Data Source: Processed Data

From the recapitulation of the table above, it can be seen that the perceptions of customers who are members of Bank Syariah Indonesia, namely Bank Syariah Mandiri, BNI Syariah and BRI Syariah, can explain that those who know about the merger of Islamic banks under the BUMN are $77.14 \%$ and the rest are not. knowing $22.86 \%$. The high level of customer literacy related to this merger will make it easier for the Bank team to carry out the acceleration process. Although the banks also need to conduct more intense education so that customers who do not know about the merger, as much as $22.86 \%$, immediately know and prepare for the account migration process later.

Regarding the decision to remain a customer, the average customer of Bank Syariah Mandiri, BNI Syariah and BRI Syariah stated that they would remain customers of Bank Syariah Indonesia, which was $74.29 \%$ of the total customers. This number is quite large, although judging from the existing data, customers who state that they are no longer customers are $2.86 \%$ and those who are in doubt reach $22.86 \%$, which means that there are still quite a large number of customers who have the opportunity to leave their status as Indonesian Islamic Bank customers.

In addition, Islamic Bank customers are also faced with questions about exclusivity. Will Islamic banks become exclusive in the sense that they will prioritize financing at the upper middle level. On average, respondents answered yes by $23 \%$, answered no by $29 \%$, and those who answered unsure were $49 \%$. This shows that the level of trust of Islamic bank customers is still relatively high because many believe that this bank will not be exclusive even though on the other hand. Many of the respondents also believe that this Indonesian Islamic bank will be exclusive.

In terms of customer knowledge, it is related to Bank Indonesia Regulation (PBI) number 17, regarding the allocation of banking funds to be given to credit/financing for micro, small and medium enterprises (MSMEs). Seen from the results of the table recapitulation, many customers who become entrepreneurs do not know about the PBI, as many as 53\%, while as many as $47 \%$ know the regulation. Judging from the percentage, it can be said to be relatively stable, because the difference is not too far between those who know and those who don't. In this case, Indonesian Islamic banks need to socialize financing programs intended for customers who have micro, small and medium scale businesses.

Then the next table is about customer distrust regarding the post-merger 
program for Indonesian Islamic banks. Customers are not sure about this sharia bank program to prioritize micro, small and medium enterprises (MSMEs). It can be seen that as many as 35\% answered yes, $19 \%$ answered no, and answered 46\% answered doubtful, meaning that the level of customer confidence is relatively low. Related to this data, it means that Indonesian Islamic banks need to educate about the existence of Islamic banks, whose main program is to facilitate the need for funds for business capital, especially those still on a micro, small and medium scale.

Customers are also not sure that Indonesian Islamic Bank will operate effectively as of November 2021. This can be seen from the answers of respondents who answered yes by $43 \%$, answered no by $16 \%$, and those who answered $41 \%$ were hesitant. This means that in general customers are not sure that Indonesian Islamic Bank can be effective as of November 2021. In this case the bank management has made this effort to accelerate the merger so that in August it is hoped that it will officially become a complete Islamic bank under one company.

Bank Syariah Indonesia will be bigger and growing rapidly because the average customer believes that this bank will be bigger and stronger. This can be seen from the answers of customers who answered yes by $49 \%$, who answered no by $10 \%$ and those who answered doubtful by $41 \%$. Although the average customer answered confidently, most of the customers still answered doubtful. The high hopes of the Riau businessmen who are customers of the Indonesian Islamic Bank is a big hope that this bank will develop and progress.

This customer from the Riau business community is also convinced that the merger of this BUMN Islamic bank is due to the influence of political elements or political will from the current government. This can be seen from the perception of customers who answered yes by $31 \%$, answered no by $26 \%$ and those who answered doubtful by $43 \%$. This means that the level of customer confidence in Indonesian Islamic Banks operating under the influence of political elements is relatively high. Political influence as support for this merger is very much needed to support the growth and development of Islamic Bank Indonesia, because without political support this Bank will face obstacles. This is because this bank is part of the state assets with the status of a StateOwned Enterprise (BUMN).

Customers also believe that there are many problems faced by BUMN Islamic Banks so that the bank then merges. This can be seen by the percentage who answered yes by $33 \%$, answered no by $30 \%$ and answered $37 \%$ possible. This means that the customer assumes that there are many problems faced so that this Islamic bank merges. Regarding these problems, it could be a barrier to the progress of Islamic Bank Indonesia. Although in essence this can also be an opportunity to survive even more advanced if it is supported by good management, both human resource management, financial management, marketing management, operations management and risk management that will be carried out.

Customers are not sure about the Indonesian Islamic Bank which will become the icon of the World Islamic Bank after the merger of the bank. This can be seen from the customer's response that as many as 36\% answered yes, 14\% answered no, and $50 \%$ of them answered doubtful. This means that the level of customer confidence 
is relatively low. In this position, Stakeholders of Indonesian Islamic banks must make a really mature plan with the strength of capital, infrastructure, human resources and a truly world-class system to be able to realize the ideals of becoming the mecca of world Islamic banks.

\section{Conclusion}

Based on the above discussion, it can be concluded that the perception of Riau Muslim entrepreneurs on the joining of BUMN Islamic banks, in this case Bank Syariah Mandiri, BNI Syariah and BRI Syariah to become Indonesian Islamic Bank, which is abbreviated as BSI, generally has different perceptions, many of which provide support even though there are also those who do not agree with the joining of the BUMN Islamic Bank. Many businessmen who were respondents in this study were not convinced that the merger of Islamic banks became the icon and direction of the world's Islamic banks, they considered the joining of these banks to be heavily influenced by political elements among the political elite known as political will (political support). actually really needed this bank to accelerate progress. It is evident that among Riau Muslim entrepreneurs on average they will continue to be customers of Indonesian Islamic Bank, because apart from being a sharia bank that is protected from usury transactions, which are forbidden, these Riau businessmen, who are predominantly Muslim, also express great support for the merger process of Islamic banks. become a major asset of this country under stateowned enterprises (BUMN).

\section{Bibliography}

Achmad Sani Alhusain, Bank Syariah Indonesia: Tantangan Dan Strategi Dalam Mendorong Perekonomian Nasional, Pusat Penelitian Keahlian DPR RI, Bidang Ekonomi Dan Kebijakan Publik Info Singkat Kajian Singkat Terhadap Isu Aktual Dan Strategis Badan, Vol. XIII, No.3/I/Puslit/Februari/2021.

Arafah, W., \& Nugroho, L., 2016. Maqhashid sharia in clean water financing business model at Islamic bank. International Journal of Business and Management Invention, 5(2), 22-32.

Aribawa, D., 2016. Pengaruh literasi keuangan terhadap kinerja dan keberlangsungan UMKM di Jawa Tengah. Jurnal Siasat Bisnis, 20(1), 1-13.

Diana, Rita. 2019. "Analisis Aksesibilitas Permodalan Mikro Kecil Pada Lemabag Formal Di Provinsi Sumatera Barat." Jurnal Ekonomi Dan Pembangunan 27(01).

Hadi, Sutrisno. 1990, Metode research jilid 2, Yogyakarta:Andi Offset.

Hassan, M.K. and Kayed, R.N., 2009. The global financial crisis, risk management and social justice in Islamic finance. ISRA International Journal of Islamic Finance, 1(1), pp.33-58.

Hisan, Khairatun, Riski Syahpitri, and Zulkarnaini Zulkarnaini, 'Determinants of Financing Disbursed by Islamic Rural Banks (BPRS) in Indonesia', EKONOMIKA SYARIAH: Journal of Economic Studies, 5.1 (2021), 50-58

Hutauruk, Fauziah Nur, 'Ukuran Perusahaan Sebagai Pemoderasi 
EKONOMIKA SYARIAH:

Journal of Economic Studies
e-ISSN: 2614-8110

p-ISSN: 2614-7890
Dalam Hubungan Profitabilitas Dan Likuiditas Terhadap Struktur Modal Bank Umum Syariah', EKONOMIKA SYARIAH: Journal of Economic Studies, 4.2 (2020), 136 $<$ https://doi.org/10.30983/es.v4i2.36 $33>$

Marabona Munthe, Fatwa Bunga Bank Perspektif Maqashid Syariah, Jurnal Ekonomi Islam Al-Amwal Vol 9, No. 1, Juni 2020. 2020, Lembaga

Keuangan Syariah (Bank dan Non Bank), Jakarta: Pustaka Amanah.

Mohd. Winario dan Husni Fuaddi, Penerapan Fatwa DSN MUI pada Pembiayaan Murabahah BPRS Hasanah Pekanbaru, Islamic Business and Finance (IBF), Vol. 1, No. 2, Oktober 2020.

Mohd. Winario, dkk, Analisis Penerapan Pembiayaan Akad Murabahah Bank Rakyat Indonesia Syariah (Bri
Syariah) Pekanbaru, Indonesian Interdisciplinary Journal of Sharia Economics (IIJSE) vol. 3. No. 1 Juli 2020.

Mohd. Winario, penerapan fatwa dsn mui pada pembiayaan murabahah Bank riau kepri syariah pekanbaru mapan: Jurnal Manajemen, Akuntansi, Ekonomi dan Perbankan Vol. 1, No. 1, Oktober 2020.

Nurcholis, M., 2018. Ihdad bagi suami dalam kompilasi hukum islam perspektif maqasid al-shariah. Falasifa: jurnal studi keislaman, 8(2), 214-228.

Purnamasari, F., \& Darmawan, A., 2017. Islamic Banking and Empowerment of Small Medium Enterprise. Etikonomi, 16(2), 221-230.

Wajdi Dusuki, A., 2008. Banking for the poor: the role of Islamic banking in microfinance init atives. Humanomics, 24(1), pp.49-66. 